\title{
MEASURING MICROFINANCE ACCESS: BUILDING ON EXISTING CROSS-COUNTRY DATA
}

\author{
Patrick Honohan ${ }^{1}$
}

\begin{abstract}
Given the acknowledged need for a new effort to expand the set of available data on direct access to financial services, including a focus on access by those at low income, the paper provides a selective review of the diverse sources of data that exist and considers how best to build upon them. It proposes a basic framework within which the analysis of the interesting questions: (i) how does access affect poverty and productivity and (ii) what hinders access, can be considered. The existing and potential contribution of user surveys, both household and business, as well as from surveys of providers and their regulators, and of experts is discussed with an assessment of their relative strengths.
\end{abstract}

Prepared for the UNDP, World Bank and IMF Workshop

Data on the Access of Poor and Low Income People to Financial Services

Washington, DC, October 26, 2004

World Bank Policy Research Working Paper 3606, May 2005

The Policy Research Working Paper Series disseminates the findings of work in progress to encourage the exchange of ideas about development issues. An objective of the series is to get the findings out quickly, even if the presentations are less than fully polished. The papers carry the names of the authors and should be cited accordingly. The findings, interpretations, and conclusions expressed in this paper are entirely those of the authors. They do not necessarily represent the view of the World Bank, its Executive Directors, or the countries they represent. Policy Research Working Papers are available online at http://econ.worldbank.org.

\footnotetext{
${ }^{1}$ Financial Sector Operations and Policy Department \& Development Economics Research Group, World Bank. I am indebted to Bob Annibale, Christina Barrineau, Thorsten Beck, Stijn Claessens and Asli Demirguç-Kunt for helpful comments, and to Ying Lin for excellent research assistance.
} 


\section{MEASURING MICROFINANCE ACCESS: BUILDING ON EXISTING CROSS-COUNTRY DATA}

\section{Introduction}

The workshop for which this paper was prepared was called to consider the need for a new effort to measure direct access to financial services with a focus on those at lowincome. The paper provides a selective review of the diverse sources of data that exist and considers how best to build upon them.

The financial sector is often considered to be the best-documented in terms of statistics. In some markets price and transaction data is available on a minute-by-minute basis or even more frequently. Yet one can look in vain for a table showing, on a comparable cross-country basis, the percentage of households with a savings or deposit account, let alone a clear picture of the characteristics of these households (income levels, regions, etc). Comparable information on borrowing is also lacking: we have information about the total value of lending by financial intermediaries, but we do not have systematic information for example about how many households or micro-enterprises are borrowing, or how much they are paying in interest. Information about insurance and money transmission services has been equally deficient.

Up to now, there has been no wide consensus on what data is needed in this area, or indeed on whether it should be seen as a priority area. For example, the Fund's General Data Dissemination Standard (GDDS) does not include this area at all, ${ }^{2}$ nor does the UNDP's Human Development Report. The Bank's World Development Indicators also lack any specific information on access to finance. On the other hand, quite a lot of relevant data of varying quality and covering widely different aspects has been collected by a variety of agencies over the years.

It is increasingly clear that a wide range of private and public sector data users do have a growing interest in identifying who has access to what financial services. This kind of information is crucial, for example, in helping financial service providers to design better ways of delivering better services profitably on a significantly larger scale than at present. They need to know more about potential market size, product and service needs and price sensitivity. Policymakers, both at the national level and in bilateral and multilateral donor agencies, as well as concerned NGOs, have a somewhat wider perspective, inasmuch as they are concerned with the effectiveness of their interventions in achieving wider public policy goals. But they too seek to know who does - and does not - have access to financial services and at what price, as well as which services are of most value to poor and low-income households. This convergence of information needs between public and private interests confirms the value of more data collection in this area.

\footnotetext{
${ }^{2}$ Unless it be deemed covered under "access to basic services" cf. http://dsbb.imf.org/Applications/web/gdds/gddshome/. I do not pursue the suggestion which some have made informally that access to basic financial services should be seen as a pre-requisite for basic economic functioning (added, for example, to basic nutrition, healthcare, education, shelter etc.).
} 
If a new data collection exercise is to be of lasting value and take its place alongside other important international data collection exercises it needs a clear conceptual framework. Ultimately, national authorities will become the main collectors of such data; but such efforts will have far greater impact if the collection is designed to approximate a common internationally accepted framework. Both demand and supply considerations are relevant in interpreting data on actual usage of financial services; if it is to yield useful results, the data collection exercise must contribute to understanding both sides.

(i) The demand side evidently includes the contribution of financial access to household wellbeing and firm productivity. Providers and policymakers both need to learn which dimensions are most important here, given their concern with willingness to pay (providers) and impact of policy success (policymakers).

(ii) The supply side entails measuring cost conditions and other barriers to access, with a view to easing or eliminating them. Here again the results are crucially important both in terms of improving design of product and service provision (providers) and benchmarking the design of financial sector policy reform (policymakers).

For each goal I suggest that there is already at least the skeleton of an appropriate conceptual framework.

We will argue that four different channels of data collection will still be needed into the future. Thus even with more in-depth inquiries from:

(i) providers of financial services (whether directly or, probably better, through national regulators), these will still need to be supplemented by surveys of

(ii) user households and

(iii) enterprises. In addition,

(iv) expert surveys will also help to fill in some details at low cost.

The outputs should include

(i) a limited number of national basic indicators collected on a broadly comparable basis across countries and updated every few years - I tentatively suggest about half a dozen indicative headings under which these could be classified;

(ii) national microeconomic databases allowing for detailed research including market research.

The paper is arranged as follows. Section 1 discusses the goals of data collection and the overall conceptual framework that could guide the exercise. The remainder of the paper then proceeds to set out the different types of relevant data that have been collected and to provide an indication of the extent, depth and frequency of coverage. In Sections 2, 3, 4 and 5 I describe what is available respectively from household and enterprise surveys, 
provider surveys and expert surveys. Section 6 concludes by considering where the major gaps appear to lie. I argue that the different approaches to data collection are complementary. They also involve sharply differing collection costs, which is an aspect not fully explored here. I also note that some existing data sources have not yet been as widely used as they could be.

\section{The data gaps and how to approach filling them}

\subsection{Existing shortcomings}

Perhaps the most widely asked question in this area is: "What proportion of the population in each country have access to financial services?" Yet, despite the work of Christen et al. (2004) - who have gone further than anyone else in attempting quantification of this type - we really don't have a good answer to this question. There are several reasons for this astonishing gap (Honohan, 2004).

They include the fact that many different types of financial institution provide such services and they record their activities in a variety of different ways that are hard to aggregate. Even poor households may use formal commercial banks, national postal savings or agricultural banks, cooperative credit unions and other entities which do not consider themselves to be specialized microfinance institutions. It is therefore not enough to count the number of customers of specialized microfinance institutions. And, while specialized microfinance entities may generally try to keep records of how many customers they have, this is often not true of mainstream financial institutions such as banks, which often organize their data around accounts rather than account holders, and which are more concerned with dollar aggregates than numbers of customers.

Even to the extent that financial service providers have, or could have, the elements of this data, regulatory agencies such as central banks generally have little interest in collecting it. That is because these agencies have different primary functions such as inflation control and preserving financial stability. These functions do not require collecting information about the large number of small deposits or loans; it is chiefly the total value of monetary and credit aggregates, and the large individual borrowings, that matter for these functions.

Furthermore, even if we knew how many active ${ }^{3}$ saving or depositing customers each institution had, we don't know how many of these have accounts at multiple institutions.

An alternative perspective begins by asking "how widespread and effective is microfinance". Getting an answer to this variant of the question is no easier. Besides, it is less interesting. Indeed, defining the appropriate dividing lines between what should be treated as microfinance, whether in terms of the providers, the type of users and the type of financial services, raises a whole new set of problems (discussed in more detail in Appendix A of Honohan, 2004). Arguably this way of posing the question is less fruitful

\footnotetext{
${ }^{3}$ Savings accounts often remain open with a small, but perhaps forgotten balance - including these can be misleading.
} 
than the more holistic approach looking at the financial services industry as a whole, and the distribution of the characteristics of its small-scale and low-income users.

Of course, similar questions arise in regard to borrowing customers and insurance, and to various forms of small value payments services.

Even if we had a credible measure of the penetration of financial services as a proportion of the population, it would not satisfy our curiosity for long. We also want to know how many poor people have access, we would want to explore different types of each service (residential mortgages $v s$. six-month crop loans) and ask about the price at which they are available to different classes of people.

There is some potential for extracting more and better data from financial service providers and their regulators (and this is reviewed in Section 4 below), but the difficulties already mentioned underline the need for seeking other sources of information such as household and enterprise surveys (Sections $2 \& 3$ ). It is also clearly essential to ensure that any such efforts start out with questions that are both answerable in a way that is comparable across countries, and contribute to building a systematic picture of access to financial services allowing private and public sector interests to be served. In short, there must be a coherent conceptual framework.

\subsection{The conceptual framework for data collection}

\section{Framework underlying other international databases}

The most successful international data collection exercises on national economic conditions have been driven by the attempt to quantify powerful underpinning economic models.

Most prominent among the international economic databases is the System of National Accounts (http://unstats.un.org/unsd/sna1993/introduction.asp), originally built on the Keynesian IS-LM model and requiring the classification of aggregate national economic transactions into income and expenditure, consumption and savings, investment and the balance of payments. Monetarist developments of the same Keynesian system underlie the depository corporations survey (formerly known as the monetary survey - cf. the IMF's Monetary and Financial Statistics Manual http://www.imf.org/external/pubs/ft/mfs/manual/) which is the bedrock of central banking data, and which classifies the assets and liabilities of banking and monetary institutions into monetary and credit aggregates. Collection of national data consistent with these two systems have allowed the evolving understanding of macroeconomic and monetary processes, as learnt from the experience of certain well-studied countries, to be verified and applied on a global basis thereby in particular offering an important technology transfer to developing countries.

International comparisons of living standards have also relied on unifying theoretical constructs. For example, the theory of price indexes based on utility theory underlying the purchasing power-parity calculations of the Penn World Tables and similar exercises taking into account international differences in the price of consumer goods thereby 
allowing a more robust comparison of living standards. Adequate measurement of living standards has long underpinned the frequent surveys of consumer goods prices and less frequent microeconomic surveys of household expenditure, which in turn have allowed calculation of poverty and inequality measures themselves often based on an elaborate and sophisticated axiomatic framework (Atkinson and Bourguignon, 2000).

When it comes to micro analysis of individual firms, including financial institutions, conventional business accounts - increasingly harmonized worldwide -- provide a unifying format. To take the case of banks, by simply assembling published financial accounts of the major banks worldwide (and not requiring any special survey effort), a commercial firm (Bureau van Dijk) has produced the large Bankscope database that has been extensively used for analyzing international differences in banking conditions and performance. (More systematic cross-country compilations for various national aggregates of banking institutions are included in the OECD Profitability of Banks publication - though only for 30 industrial countries).

The hallmark of these systems is the attempt to cut through inessential or superficial differences in national concepts by define a reduced set of primitive concepts and provide guidance as to how to map national measures onto the primitive concepts. It is in this spirit that the proposed development of national basic financial access indicators should be seen.

The task of assembling data on financial access and microfinance still awaits its guiding conceptual framework. It is not enough to measure financial service usage. We also need to understand it. To do so, what could be more natural than to distinguish between the demand and supply side of the question? First, of what benefit is financial access; second, what hinders access?

\section{The demand side: Benefits of access}

In principle, and given enough knowledge, poor and low income households should be willing to pay for financial services up to the cash equivalent of the services value to them. There will be external benefits also, but the direct benefits are likely to dominate. This is why, although private and public sector perspectives on the benefits of access might initially seem far apart, in reality there is considerable overlap. The commercial financial service provider is primarily concerned to assess willingness to pay. But this in turn depends on the value placed by the household on the financial service in helping its overall welfare - which may often be measured in terms of money income equivalent, especially recognizing that this includes the effects on enhancing household members' productivity as producers.

The public policymaker might at first sight seem to have a wider perspective. For example, it might seem natural to the public policymaker to organize any discussion of benefits around the Millennium Development Goals (MDGs). ${ }^{4}$ Indeed, as has been

\footnotetext{
${ }^{4}$ The eight MDGs are in brief: 1. Eradicate extreme poverty and hunger; 2. Achieve universal primary education; 3. Promote gender equality and empower women; 4. Reduce child mortality; 5. Improve
} 
documented by Littlefield, Morduch and Hashemi (2003), with one or two exceptions, direct access of poor people to financial services can strongly affect the attainability of each of the MDGs, even those which chiefly require upgrading of public services in health and education, etc, as these also require poor households to be able to afford access, including the opportunity cost of foregone child labor services (cf. Beegle et al. 2003). But in practice it is the impact on the level and stability of household income and hence in reducing household income poverty (MDG1) - that will be the dominant channel. $^{5}$

Thus, from their slightly different perspectives (willingness to pay, impact on welfare) both public and private sector users will be interested in the benefits to households of financial access. (Public policy will also be interested in externalities ${ }^{6}-$ but even some $^{2}$ of these, if sufficiently local, may be partially captured by private providers).

The emerging theory of the role of financial services in income growth can be appealed to as the basis for an initiative in the area of data collection on access of the poor and microenterprises to financial services. This theory has been developed for understanding the linkages between national financial systems and economic growth, but some of the elements point to a theory of inclusive finance that is in practice pro-poor, and within that to direct impacts of finance on the asset base, income and income security of low-income households and the security, productivity and profitability of micro-entrepreneurs. ${ }^{7}$

Thus, specifically, if as suggested by Levine (1997) and many others since, the functions of finance to the economy at large include

- Payments (inland and international remittances - crucial for families dependent on migrant income)

- Savings mobilization (depositary services)

- Allocation of capital funds (conditions for access to credit)

- Monitoring users of funds (mechanisms for building creditworthiness)

- Transforming risk (insurance, etc),

these functions could be the basis of a useful set of financial access indicators, as further discussed in Section 6 below.

maternal health; 6. Combat HIV/AIDS, malaria and other diseases; 7. Ensure environmental sustainability; 8. Develop a global partnership for development.

5 Though some may also want to single out the potential contribution of financial access to the empowerment of women (MDG3). The idea that access of women to financial services can be particularly empowering is an attractive though not unchallenged one. This area raises important sociological issues that would need to be considered in the data exercise, but that will not be addressed here.

${ }^{6}$ Government's interest in wider access can also lie in other directions: reduced cost and higher security in delivering pensions and other payments; reduced potential for money laundering.

${ }^{7}$ Does the "low income" apply also to the micro-entrepreneur? Surely yes. Otherwise the exercise becomes totally subsumed in the wider issue of indirect impact on poverty and inequality of financial sector development, which may not have much to do with direct access of low income people to financial services. 
Each of these functions has its microeconomic counterpart (examples are bracketed above) relevant to the low-income household or microentrepreneur. While the potential for poverty alleviation of access to credit and insurance facilities is easy for all to imagine, the others are also not negligible. For instance, the dramatic fall in the retail price of international money transmission from the US to Latin America was sufficient to allow a regular remittance of $\$ 200$ to be increased to $\$ 215$ for the same net cost to the remitting emigrant - an appreciable potential contribution to poverty alleviation in the home country (Orozco, 2004). The value of small savings mobilization facilities to the poor has been established by observation of the heavy transactions costs the poor are prepared to pay for such services (Rutherford, 2001).

However, despite much detailed work that has been done over the past decade or so evaluating various donor-funded microfinance initiatives, it has to be said that the magnitude of the impact on household poverty of improved access (cost and availability) to each of these services is not well-known. Partly this is the result of researchers in impact studies trying to measure too many dimensions of the impact of service-enhancing policy or donor interventions (Honohan, 2004). Evidently collecting information about the access of households and firms as well as on their income and productivity is key to addressing these issues, and equally important is collection of additional information about the users' characteristics to be used as controls.

\section{The supply side: What hinders access?}

If access to financial services has an impact on poverty reduction, the other side of the coin is to explore the determinants of such access. Here there is less agreement on a framework for analyzing the determinants of access for low income households.

There is something to be learnt from the experience of high income countries in dealing with the problem of exclusion from financial services. But, on closer consideration, the problem being addressed in the advanced economies is different in several key respects, mostly associated with the fact that advanced economies have reasonably wellfunctioning financial systems from which only a small minority are excluded from access. In both the US and the UK, for example, fewer than 10 per cent of households are totally excluded from the mainstream financial sector (cf. Kempson et al., 2000). There, the problem is of dealing with a excluded minority, whereas in the low and middle-income countries the problem is one of reaching with financial services what is often an overwhelming majority of the population. For instance, in advanced economies, considerable progress might be made by existing providers designing and adding simpler products with lower unit costs that can meet the less complex financial needs of lowincome households, or facilitating the emergence of niche players that can more effectively reach the excluded. But in lower income countries the challenge may involve existing intermediaries scaling up to a multiple of the number of their existing clients, or large new providers entering the market with a new business model.

Nevertheless, insights from the advanced economy literature are helpful. Here we propose, as a variant on what has been suggested in various other studies ${ }^{8}$, that the

\footnotetext{
${ }^{8}$ For example, Kempson et al. 2000 distinguish between five types of exclusion to financial services:
} 
barriers to access should be classified into price barriers (service is available but too expensive), information barriers (e.g. poor household's creditworthiness cannot easily be established) and product and service design (banks fail to offer the kind of services that would be most useul for poor households). Data on these aspects would be both essential for research purposes and a natural frame for the purpose of national summary statistics on barriers. Behind each of these barriers may be technological, regulatory or market factors (such as lack of competition).

Price barriers: Evidently the all-in cost of accessing any service is an important determinant of the degree to which the service will be used. This will include both the price charged by the service provider and the additional costs incurred by the household in accessing this service. For the price charged by the service provider, technical efficiency, regulatory and tax factors and competition (or lack of it) are all relevant drivers. For the additional costs incurred by the household, cost and availability of transport and communications infrastructure, given branch location, will be relevant.

Information barriers: An extensive literature on credit rationing due to adverse selection points to the importance of information aspects. Evidently these can effect the cost of credit or even make it unprofitable to extend credit to certain groups at any price. A range of policies is available to alleviate this whether by improving information or reducing the need for it. For example, the establishment of an improved credit information infrastructure can be eased by enabling laws and by steps to overcome the collective action problems that are often involved. Improved procedures and laws relating to secured lending, leasing and factoring help overcome information gaps by reducing the need for information. (Of course, information gaps are not external to the system, but can also be affected by behavior of market participants, for example, through improved financial product design.)

Product and service design barriers: Surveys often reveal that the products and services offered by financial intermediaries are not well-adapted to the needs of poor people. This can apply even in respect of specialized microfinance institutions, for example if they insist on group lending mechanisms in areas where this does not fit comfortably with social norms. The repayment terms of loans may not reflect borrowers' cash flow patterns. For example a coffee farmer may need credit with balloon payment structure reflecting the cash-flow inherent in that crop. Likewise, the need for daily vendors to have daily loans and repayment systems may not be recognized. Or again MFIs may neglect the need to provide a door-to-door savings collection mechanism in areas where women do not readily leave their houses. More generally inaccessibility of branch locations is a widespread problem in rural areas. (In some of these cases, it is hard to see

(i) access exclusion: e.g. through risk screening;

(ii) condition exclusion: product design inappropriate for the needs of some people;

(iii) price exclusion: financial products too costly;

(iv) marketing exclusion: with some people effectively excluded by targeting marketing and sales;

(v) self-exclusion: some persons not applying in the belief that they would be refused.

For an alternative classification of access barriers, see the discussion of the Southern Africa studies below. 
what is stopping mainstream financial institutions from adopting the needed innovations. Perhaps here too a lack of competition may removed the pressure to innovate.)

Such mismatches are even more apparent when it comes to some of the main services typically offered by mainstream institutions such as the traditional demand deposit/current account with checkbook. This is a costly-to-provide product bundling powerful transactions services with high liquidity for those whose creditworthiness allows them to have their cheques widely accepted. But it is accordingly costly and very risky for poor borrowers, given the price imposed for bounced cheques (NSF charges) - a material risk for low-income households. In reality, poor customers do not need all of the bundled services and will often reject this product but do have a higher demand for a limited service transaction account as has been advocated in advanced economies (Kempson et al. 2000), and implemented in some developing countries. Likewise, common complaints to mainstream institutions about such features as high minimum balance and compulsory collateral for loans can be seen as the consequence of rigid product design (rather than being complacently attributed to unavoidable transactions costs). ${ }^{9}$ Other examples of unsuitable product and service design from mainstream institutions are exclusive reliance on interactions that demand onerous paperwork from illiterate or barely literate customers.

Accepting this framework, it is clear that household characteristics, service provider characteristics, and wider environmental characteristics, all are relevant in understanding the importance of different barriers to access and thus potentially in identifying feasible solutions. The framework proposed can be tested and quantified: regression of access indicators on household and other characteristics can help pin down the effects.

A largely parallel discussion applies equally to access of micro enterprises operated by low income people or in low income areas.

Thus "what hinders access" points to a widening of the net for the information gathering beyond the users of financial services to the providers and their management, organization, strategies, cost structures, and operating environment. Key national basic indicators here could include measures of the cost of selected standard services, and availability of information/credit infrastructures.

\section{Alternative sources of information}

The discussion clearly points to the need for a range of different sources of information. The needed data collection exercises can conveniently be grouped by the type of respondent, i.e. the person or organization which is supposed to have the information being collected. Essentially there are three, namely users and providers of financial services, and experts of which the first can be subdivided into two classes, household users and business users, giving four types overall. Increasingly the build-up of national statistical collection capability implies that, in many cases, the primary surveys of these

\footnotetext{
${ }^{9}$ Certain observers stress psychological aspects such as the values and attitudes of the household as additional types of determinant (the relevance to Islamic households is evident, see also the discussion below of Southern African surveys).
} 
ultimate information sources will be carried out by national statistical agencies (through censuses or household or enterprise surveys) or regulatory agencies or providers of other public services (through their administrative records). Examples of these are provided below.

\section{Household users}

Surveys of households are at once the most direct and the most costly ${ }^{10}$ way of discovering information about access to financial services. In general, members of the household do have most of the information, and not only on what financial services they use, with what frequency and at what cost. To be sure, the household member may not be willing to share that information, especially if probed about the size of their financial asset holdings, or indeed their indebtedness. And a single respondent (head of household) may not be fully informed about the services used by other members of the household. The desire for secrecy in these matters does complicate the information gathering exercise, and there can be significant reporting and response biases. ${ }^{11}$

A key question is the relative merits of a stand-alone specialized financial services survey and the introduction of a financial module in a general household survey. The former has the attraction of allowing greater detail in the questionnaire instrument. Given the practical limitations on administering lengthy questionnaire instruments, a finance module embedded in an overall general purpose household survey will typically be limited to just a few questions. Also the sample frame can be adjusted to oversample groups or geographical areas of particular interest to the financial researcher.

On the other hand, a "finance-only" survey will naturally tend to be more costly than the finance compone nt of a general survey, because it will be bearing all of the overheads. Furthermore, it will tend to offer a more limited range of non-financial control variables and correlates ${ }^{12}$, and as such the range of research questions that can be answered will be constrained and the reliability of those that can may be somewhat compromised.

The purpose for which the data is being collected will also color the choice between stand-alone and embedded surveys, and will also, of course, influence the questions that are to be included. If the focus is purely on market research aimed at understanding the scale and determinants of the demand for different financial services, a shorter (albeit more specialized) list of questions will likely suffice than if the focus is on the influence of different forms of financial market access on household poverty, or on the determinants of household access.

\footnotetext{
${ }^{10}$ Justifying and quantifying this and other assertions about the relative cost of different modes of data collection is beyond the scope of the present paper, but should be an early priority.

${ }^{11}$ When grossed-up to national totals, household surveys of financial asset holdings systematically understate the reality, mainly attributable to non-response bias (richer households refusing to participate) and to respondents falsely reporting zero holdings of certain assets). Interestingly, where respondents reported non-zero holdings it seems (from circumstances in which independent verification was possible) that their reporting errors are unbiased (Ferber, 1965).

${ }^{12}$ For instance, LSMS surveys ask hundred of questions and typically report in detail on health, education and employment status of each household member as well as on income and expenditure patterns. Most also ask about migration, fertility, agricultural activities and anthropometry (personal height, weight etc.).
} 
I will now discuss three selected examples of the use of household surveys, namely (i) those carried out under the LSMS program; (ii) other general household surveys and (iii) specialized financial services surveys. ${ }^{13}$

\section{LSMS surveys}

The World Bank's LSMS was a pioneering effort to extend the use of best practice in national living standards surveys worldwide. The LSMS website reports on 51 surveys covering 30 countries at various dates since 1985. Of these, 39 surveys, covering 25 countries, included a module on "savings and borrowing" and a handful of others also include some savings and borrowing questions in other modules. (The Annex Table summarizes the main questions asked in this module in 27 of these surveys). The content of this module varies from survey to survey - indeed a degree of variation is inherent if the questionnaire is to reflect local conditions and as such resonate with the respondent but recent surveys have contained useful though limited information mainly about credit. The sample sizes typically range between 1500 and 7500 which is sufficient for low sampling errors on nationwide totals, but small if subgroups are to be examined.

For instance, the 2001 survey for Bosnia interviewed 5400 households and included a credit module ${ }^{14}$ ) containing 13 questions. These ask (i) how often the respondent borrowed from identified sources in the previous 12 months, together with flow and stock amounts; (ii) from whom, how much and why the latest loan was obtained (and if none why not); (iii) whether and by whom loan was refused. Other financial service questions are also embedded elsewhere in the questionnaire. For example, items 42 and 43 of the 48-item expenditure survey are spending on insurance and other financial services including bank charges.

A 1998 survey for Ghana interviewed about 6000 households included as the last section a "credit, assets and savings" module (Section 12). Here credit respondents were asked (i) in respect of each loan obtained or repaid in the past 12 months, the amount, the source, the purpose, what guarantees were required by the lender and what repayments have been made and (ii) whether and why any loan application was refused. Any savings accounts (including informal susu accounts) were also measured together with flows in and out. Household spending on "financial services not elsewhere specified" was also requested.. Questions on credit were also asked in respect of household-controlled enterprises. Here were required the main sources of finance and of credit, whether a credit application was refused and gross borrowings and repayments in a twelve month period.

\footnotetext{
${ }^{13}$ I will not attempt to benchmark these against the leading comparators in the advanced economies such as the US's Survey of Consumer Finances, the UK's Household Resources Survey or the Italian Survey of Household Income and Wealth. The enormous economies of scale in statistics collection militates against such comparisons especially in respect of small economies.

${ }^{14}$ Interestingly this module was placed no. 6 of 13. Most interview designers in contrast prefer to leave the sensitive financial modules to the end of the interview to avoid offputting effects that might damage response quality for the other themes.
} 
In the case of Vietnam, where about 6000 households were interviewed in 1997/8, the penultimate module of the questionnaire (Section 14) deals with credit and savings.

Respondents are asked detailed questions (up to 28 in number) for each borrowing relationship: from whom (including size and age of a ROSCA and, in the case of a family relative, what the relationship is and whether it involved borrowing and lending before), how much, when, why, rate of interest, what type of collateral, whether a family relative gave a guarantee, maturity, servicing schedule, whether any servicing difficulties are foreseen. For each lending relationship to a ROSCA, family relative or other person, a similar set of questions was asked. Also asked are the outstanding balance and frequency of use of different forms of savings, financial (savings books distinguishing between different classes of banking institution, government bonds, other bonds or equities or contribution to informal credit, local cash, dollars) and non-financial (gold, silver, gemstones, jewelry, real estate, paddy or other agricultural products). Note also that some information about financial services is embedded in the sections of the questionnaire dealing with income and expenditure: for example interest and insurance income is separately identified; as are insurance premium payments and nonbank financial asset acquisition (purchase of stocks or bonds or contribution to an informal credit scheme).

An interesting feature of several of these surveys is the geographical basis of the sample frame. In Vietnam, just 194 of 10,000 communes were surveyed. Thus the households are clustered in these communes (there is also a further level of clustering in rural communes, as two villages within the commune were sub-selected). Accordingly, general geographical information, such as distance to nearest bank need only be asked once, and this in fact has been done by administering a commune-level questionnaire, containing a section which identifies the main borrowing and savings providers, how far they are from the commune and what types of credit and savings opportunities they provide. ${ }^{15}$ Note however, that the fact that only 2 per cent of communes are surveyed, a detailed geographical mapping of such information as mean distance to nearest credit institution for the households in a particular province is not available.

\section{Other general household surveys}

General household surveys increasingly carried out by national statistical agencies outside of the framework of the LSMS can also contain useful information on financial services for much larger samples, allowing geographical and other breakdowns to be reliably considered. For example, the Tanzanian Household Budget Survey 2000-1 covered over 22,000 households. It covers education, economic activities and health status as well as household expenditure, consumption and income, ownership of durables and assets, housing, distance to services and food security. Under financial services, we learn whether the household had a bank deposit account, had received a bank loan in the past year, participated in a formal or informal savings group, and the distance to the nearest bank branch. Just five simple questions without any of the interpretative

\footnotetext{
${ }^{15}$ The same is true for the Ghana survey where the distance to bank is asked at the community level. Here about 300 enumeration areas were selected from a possible 13,000 stratified in order to achieve proportional representation of three main ecological zones in Ghana. In Bosnia, a 6-way stratification of municipalities was determined before selecting 25 out of 146 urban and rura 1 municipalities to sample.
} 
elaboration of the other surveys discussed, but nevertheless of considerable value. (For instance it revealed a sharp decline in the number of bank account holders (from 18 to 6 per cent of the population) in the nine years since the previous survey. Research exploring the correlation between banking and other household characteristics would be possible, though (as is all too often the case), this does not seem to have been carried out so far.

\section{Stand-alone financial access surveys}

Recently, increased interest in financial access has prompted a number of stand-alone financial access surveys. Evidently, such surveys can probe more deeply questions such as "why do you have a deposit account?". On the other hand, as mentioned, cost may make them thinner in terms of control variables. We mention three important recent exercises.

A World Bank initiative to improve information on household access to finance in selected Latin American countries is exemplified by work on Brazil (Kumar, 2004) ${ }^{16}$ surveyed about 1250 urban households asking similar questions on deposit and credit as in the general survey examples given above from the LSMS, with perhaps more detail, for example on the motivation for household choices and the reasons for being refused credit (though only 9 respondents answered this question!). It also extended into the different purposes for which different retail payments media were used by households. Quite a few control variables were obtained by asking questions about such matters as education, labor force status, housing and ownership of key durables. It proves important to include country-specific institutional detail in some of the questions. For example, more of the respondents reported that they used as their main financial institution not the banks, but the lottery outlets of the Caixa Economia Federal, which provides limited banking services. This is a point that might have been missed if a standard template was imposed, or in the case of if a limited set of financial questions being added to a general household survey.

Econometric analysis of the survey data threw light on a number of issues that might have remained hidden if the results had simply been tabulated, as is so often the case. For example, branch location may be less important than the precise type of housing (overcrowding) as a predictor of whether a household will have access. In addition to income, education, employment status and gender prove to be reliable predictors of financial access both on the deposit and lending side.

In contrast to the Brazil case, rural households were the focus of the recent household survey in two provinces (Andhra Pradesh and Madhya Pradesh) of India (Basu, 2004). Actually, India had been a pioneer in surveying rural access with the All-India Rural Credit Survey of 1951-2, which was repeated at intervals, but discontinued in 1991. In the 2003 survey 6000 households were surveyed and the questions focused especially on credit allowing a time-series dimension building on the earlier surveys. Source, reason,

\footnotetext{
${ }^{16}$ Parallel work is under way for Colombia and Mexico (cf. Caskey et al. 2004). The list is by no means comprehensive. In addition to other nationwide household surveys focusing on credit and finance. there have been several confined to rural areas, for example Chaves et al. (2001) for Romania.
} 
tenor and cost of borrowing were probed, as were reasons for not using formal intermediaries (including bribery: 27 per cent report having to pay a bribe to get a loan). Among the other financial questions was: type of insurance used. Not many household level control variables were mentioned in the study report, reliance being placed instead on ecological regression using village characteristics.

An important recent initiative is a suite of household surveys recently conducted by the Finmark Trust with partners in five countries of Southern Africa (Botswana, Lesotho, Namibia, South Africa and Swaziland) with broadly comparable questionnaires in the five countries. ${ }^{17}$ In contrast to many other studies, the focus of the Southern Africa surveys has so far been less on the knotty question of access to credit, and much more on cost and other barriers to use of services access to most of which does not require satisfying creditworthiness tests. Close attention is paid not only to the range of alternative financial services (life and general insurance and payment technologies) but also the reasons provided by households as to why they did or did not use the services and as to problems with using them. As such, these surveys carry some of the flavor of market research to a greater extent than the others mentioned above. An interesting feature is the use of household psychology: values and attitudes (whether family or community oriented or materialistic; general optimism; connectedness) as predictors of financial service usage. In addition, financial discipline and risk management strategies were explored. For example, households were asked questions as to what resources they had drawn on to meet various emergencies and other spending needs, or to absorb investible windfalls. They were also asked about their knowledge of and attitudes to different financial institutions (for the former making explicit use of service provider names, e.g. Barclays, FNB). As with the other market-research relevant aspects, this presumably enhances the commercial value and points to a way of spreading the cost of such surveys.

Ingeniously, the researchers (Genesis/Finmark) attempted to calculate a single exclusion index for example by considering the proportion of the population which is likely to be excluded by virtue of any of several barriers or costs, specifically affordability of the service, regulation (e.g. anti-money laundering rules; limited right of women to open accounts without husband/father's approval), eligibility (e.g. requirement to hold minimum balance, requirement to show payslip before opening account); service characteristics (queuing, need to fill forms, need to use complex technology); product features (interest rate, liquidity). Some of these are measured directly by survey response

\footnotetext{
${ }^{17}$ http://www.finscope.co.za/. Sample sizes in the initial pilot surveys of the small countries carried out in 2003 ranged from about 500 to 800; the South African pilot in 2002 had about 1000. A full scale survey using census information for the sample frame, was mounted covering 3000 households in South Africa; this is being repeated in South Africa in 2004, and there is a full-scale survey in Botswana also in 2004. Interestingly, the countries surveyed in this suite have sharply varying proportions of "unbanked' (in this case households without a savings account as a formal financial intermediary): Botswana 20 per cent; South Africa 49; Namibia 52; Swaziland 54; Lesotho 67. In South Africa, over two-thirds of those without a bank account say this is because they have no job; only 13 per cent say they don't need one or would prefer to use cash; interestingly one in seven had an account but no longer do - perhaps an especially high figure reflecting unique conditions in South Africa. In the other four countries, the high minimum balance and the banks' formal requirements (payslip etc) are cited as the main discouraging factors (Genesis, 2004).
} 
to the item as a barrier to access, some by use of independent information. For example, in the case of affordability, the authors obtain data on the all-in cost (cash plus travel time $^{18}$ ) of each service and define as excluded those with monthly income less than 50 times that service (in Swaziland $88 \%$ of households are seen as excluded on cost grounds from transactions accounts). The idea of this single index seems to be to benchmark a country's overall performance; the components of the index could point to the direction of policy solutions. While the implementation of the idea might be criticized, it does represent a creditable attempt to distill the information from household surveys in a policy-relevant manner.

A different type of household survey, the financial diary approach, attempts to document in detail the financial transactions of the poor. Pioneered in Bangladesh by Rutherford (2000), (2002), financial diaries can be thought of as an anthropological study exploring the way in which households manage their financial affairs. As such, it is more exploratory of patterns than simple quantification of pre-defined concepts. This approach has helped dispel misconceptions about how the poor employ substitutes for services that only the better-off can afford to acquire from mainstream finance. Awareness of these substitutes is a useful pre-requisite for formal institutions designing new products at reasonable cost to meet the demand of low-income clients with a viable cost structure.

\section{Business surveys}

Three main methods for obtaining information about business use of financial services are used in advanced economies. The first is from the required public reporting by widely held and listed companies. This data is readily available and has been studied by many researchers. Information about the financial service use of smaller firms is not as readily available, though there are a number of important sources. Amadeus, a commercial service from Bureau van Dijk, draws on sources - mainly credit registries in 34 European countries to provide a standardized balance sheet and income statement, 7-digit production sector, employment and ownership information for 5 million firms, most of them micro by standard EU definitions. ${ }^{19}$ In principle, this kind of material could be assembled for other countries too, but I am not aware of any cross-country effort to do this. There are also some surveys carried out by official statistical or regulatory agencies, such as the five-yearly Survey of Small Business Finances by the US Federal Reserve Board, of which the most recent, in 2003, collected financial information on some 600 firms with fewer than 500 employees (cf. Board of Governors, 2002).

Turning to the developing world, there have been a couple of major initiatives in the area of business surveys. The World Business Environment Survey (WBES) is a 81-country cross-sectional firm level survey conducted in developed and developing countries in 1999-2000 following an initiative of the World Bank. ${ }^{20}$ Typically about 100 firms were

\footnotetext{
${ }^{18}$ The researchers used the same mean travel time for all households, but this also would in general vary by household.

${ }^{19}$ Currently EU defines a firm as micro if it has fewer than 10 employees and either a turnover of less than $€ 2$ million or a balance sheet total of less than $€ 2$ million. The thresholds for small and medium firms are $(50, € 10 \mathrm{~m}$. and $€ 10 \mathrm{~m}$.) and $(250, € 50 \mathrm{~m}$. and $€ 43 \mathrm{~m}$.) respectively.

20 The WBES builds on a number of earlier exercises (including some carried out by the IFC), though its sheer scale now tends to push these others into the background. One significant study of this type was the
} 
interviewed by country, with an overall total of 10,090 firms. The aim was to have at least $15 \%$ of the firms in the "small" category (fewer than 50 employees), and in all, $40 \%$ were in this category. Nevertheless for the purpose of obtaining statistically significant results on access, the sample remains rather small in almost all of the countries. ${ }^{21}$ In addition to general information about the firm and its governance, most of the questions are qualitative ones about the firm's perception of the institutional environment in which it operates. The questions are grouped under the headings: quality and integrity of public services; rules and regulations; legal system; bureaucratic red tape; predictability; financial sector services and corporate governance; and competition.

There are five financial sector services questions in the WBES survey, relating to (i) the firm's confidence in the ability of the financial sector to deliver needed services; (ii) a breakdown of the source of the firm's financing; (iii) time taken to transfer funds; (iv) firm's rating of the extent to which 11 identified financial sector service difficulties such as bank collateral requirements; high interest rates, corruption of bank officials etc. represent an obstacle to the firm. (v) whether the firm uses international accounting standards (IAS) and provides shareholders with audited accounts.

The survey's findings have been summarized by Batra et al. (2003) and they reveal the importance of perceived financial constraints in most regions (though not in Africa). There are differences by size of firm: unsurprisingly, the use of internal funds, family and friends and of money lenders declines as firms get larger, while the use of local and foreign commercial banks and state funds increases. Small and medium sized firms have a greater propensity to report moderate or major financial obstacles than do large firms, though not in relation specifically to high interest rates which is overall the most highly rated financial constraint. The other major constraints reported were lack of access to long-term funds, collateral requirements, lack of credit information on clients and bank paperwork. (Curiously, small firms had a poorer image of the quality of the central bank than medium or large firms).

An early use of the WBES data was to explore the impact of foreign bank penetration on firm access to credit (Clarke et al.2001). Since then there have been many other uses including examination of the relation between firm growth, firms' perceived constraints and independently measured country environment variables such as bank concentration in

RPED panel study of 6 African countries in the mid-1990s and selectively updated around 1999. This covered about 200 firms per country ranging from micro (less than five employees) up to large scale employing over 1000. In the survey, questions were asked about whether firms applied for loans, if not, why not and if they applied whether applications were approved. Only about 10 per cent of firms had received a loan in the past year ( 2 per cent of the micro firms, 5 per cent of the small) with trade credit and informal sector debts together about three times as important as bank debt in the balance sheet. Interestingly, the rejection rate for firms that applied for credit was about 45 per cent -75 per cent for micro firms, 60 per cent for small, 45 per cent for medium and 20 per cent for large. Fully 20 per cent of firms ( 38 per cent of micro) said they didn't apply because they didn't have collateral or thought they would be rejected. A further 8 per cent of firms (13 per cent of micro) didn't apply because they thought the process too onerous. Others mentioned cost and overindebtedness as reasons for not applying. Only a third of all firms said they did not need credit. (Bigsten et al. 2003, who also present regressions explaining the credit rejections and discouraged borrowing as functions of national and firm characteristics).

${ }^{21}$ Furthermore, firms with fewer than five employees were generally not covered. 
studies by Beck et al. (2003a and 2003b), which illustrate the use in combination of expert surveys and firm-level surveys.

From 2002, an expanded version of the WBES known as the Productivity and Investment Climate Survey (PICS) has been running and plans to cover 20 surveys per annum with results reported so far from 49 countries (see list in Table 2$)^{22}$. The sample size per country has been increased to several hundred business establishments, and (for most countries) the focus has narrowed to manufacturing. The core questionnaire is rather longer now ( 82 questions, many subdivided), reflecting a broadening of the areas of interest, which now include innovation, labor relations and productivity as well as the areas covered in the WBES. In addition, national questionnaires may explore additional areas of specific national interest.

The finance questions of PICS now cover seven areas in more detail: sources of financing divided (miraculously) into sources for working capital and for new fixed investment; ${ }^{23}$ existence and utilization of a line of credit; collateral, interest and duration of most recent loan; currency denomination of total borrowing; speed and cost of payments system; audited accounts; whether land owned or leased.

The PICS were drawn on extensively for the WDR 2005 recently published, but no comprehensive detailed write-up of the cross-country results has yet been released.

\section{$4 \quad$ Provider surveys and administrative records}

Information can be obtained from financial services providers and their regulators regarding both the scale of operations and the degree to which their services reach household and business customers, and on the operations and management etc. of the provider itself, both of which aspects have been identified above as relevant to the questions at issue.

\section{Information published by providers}

Although much regulatory information is routinely obtained from banks and other financial service providers for regulatory purposes and also, for many banks, published for the benefit of shareholders or the general public, relatively little of this has a bearing on the small customers of interest here. For most banks the aggregate value of deposits, or loans of such customers is very small as a fraction of the banks' total business, and information about numbers of accountholders is not always retained or known. Some relevant information should be easily available from providers but is not commonly published even though not very market sensitive. This would include such information as number and location of branches and ATMs, number of accounts, size distribution of accounts, both deposit and lending and pricing of services.

\footnotetext{
${ }^{22}$ This count includes the Business Environment and Enterprise Performance Surveys (BEEPS) for Easter Europe and Central Asia which retain the smaller sample size, wider sectoral coverage and more limited questionnaire more characteristic of the earlier wave.

${ }^{23}$ It mystifies this author as to how the firm is expected to make this distinction given the fungibility of money, not only between working capital and fixed investment, but as between existing real capital and new investment.
} 
A well-known and important caveat, already mentioned in Section 1.1 above, needs to be recalled with regard to aggregating provider information on the number of accounts. The same individual, household or enterprise may have multiple deposit or loan accounts whether within a single intermediary or with many intermediaries. Furthermore, inactive accounts may not always be closed. While a well-managed intermediary should be able to identify the number of its distinct clients, and also distinguish between active and inactive accounts, this is not the case for all intermediaries in developing countries. (Furthermore, if complex multi-firm corporate structures are present, it is not obvious how the customer should be defined). A good credit registry can help uncover multiple borrowing relationships, but multiple deposit relationships will generally be difficult to discover from the providers' side. All of this implies that the total number of accounts exceeds the number of banking relationships by an unknown factor. ${ }^{24}$

Of the list of provider-sourced information, pricing of services is worth highlighting, given its importance as mentioned in determining whether poor households will buy the services in question. The underlying costs are not the only determinants of pricing. Traditional banking practice and lack of management interest in reaching a poor clientele can result minimum opening balance and minimum service fees for transactions accounts being set at fairly arbitrary levels which, though of little concern to the bank's present customers, are a prohibitive barrier to those at low incomes (in some low income countries minimum balance requirements can equal several months of average per capita income). Pricing deserves much more attention, not only in the context of changing technology that can dramatically alter the unit cost for small transactions, but also given the non-competitive environment which is often observed.

\section{Published information for specialized MFIs}

In the case of specialized microfinance providers, the situation is somewhat different, given their dual mandate of operating efficiently and reaching many target clients. A large number of country studies and studies of multi-country MFI networks throw light on the scale of outreach. Drawing on such evidence, a group at CGAP, Christen et al.(2004), have been able to put together a database setting out the number of clients reached by a wide range of microfinance suppliers, including not only specialized MFIs, but also other non-traditional intermediaries with large numbers of small clients.

The CGAP inventory aims to determine how many "poor and near poor" clients have savings or deposits at a broad range of "alternative financial institutions" including not only the "new breed" of specialized MFIs, but also for example mutuals, state agricultural and development banks. The CGAP database also includes postal savings systems and other savings banks even though they do not make microloans. As such it sets out to be a maximal data set for whatever could be regarded as alternative in the

\footnotetext{
${ }^{24}$ For example, this proble $\mathrm{m}$ is likely the source of the huge discrepancy between the aggregate number of deposit accounts reported by Tanzanian financial intermediaries - 2.23 million - and the grossed-up number of households reporting a deposit account in the household budget survey -0.42 million.
} 
sense of not being a commercial bank. ${ }^{25}$ Upwards of 750 million clients ${ }^{26}$ of an economic level "not typically served by commercial banks" are estimated for this broad category - only one in four with loans. Commercial banks also offer such services in many countries, but these are not considered "alternative" and as such are not included in the CGAP inventory. ${ }^{27}$

Despite its extensive coverage, it needs to be noted that the information on each intermediary stored in the CGAP database is rather limited: name, organizational type, number of deposit accounts, no of loan accounts, no. of members and sometimes the total value of loans and deposits outstanding. Also, it is not free of the multiple banking relationships problem alluded to above.

Shifting from their outreach to the operations of MFIs a large number of assessment reports and ratings are available for specific institutions. No attempt will be made here to summarize those. The largest cross-country database which does include a considerable amount of financial and operating information, is that assembled by the Microfinance Information Exchange (The Mix) with a summary published in MicroBanking Bulletin. This is based on a 12-page questionnaire, covering balance sheet and income statement, infrastructure (staffing, offices etc), products and clients, portfolio performance, liabilities, subsidies received. The response rate has been quite variable from year to year. More than 200 firms reported in the most recent year, but a time series is available only for a fraction of that.

\section{Seeking information from the regulator and from providers}

In an attempt to obtain further detail on a cross-country comparable basis, the World Bank has recently prepared a questionnaire for developing country bank regulatory authorities (Beck et al., 2004). In addition to regulatory matters, this covers information on branch numbers and on the number and size of different types of deposit and loan accounts broken down by type of intermediary and by class of customer (MSMEs and others, urban vs. rural) and the number and value of payments transactions. Despite concerns that many regulatory authorities might not now have the information necessary to respond fully to this questionnaire, the response rate has been good. Branching and ATM information has been obtained for almost 70 countries and average loan and deposit size information for about 30 countries..

As part of the same exercise, 300 banks in 60 countries are also being surveyed by mail with an 11-page access questionnaire asking about such matters as minimum deposit

\footnotetext{
25 The CGAP database draws on and subsumes the data assembled by the Microcredit Summit (DaleyHarris, 2003).

${ }^{26}$ About one fifth of this total comes from a very approximate imputation for savings banks based on their total assets and certain assumptions about the distribution of savings balances.

27 The largest entities included in the CGAP inventory are: the Postal Savings Banks of India, China, Korea and Egypt (the first two alone account for 234 million savings accounts - about a third of the grand total); India's Regional Rural Banks (network of almost 200 banks); China's Rural Credit Cooperatives (network of 35,000 state-owned intermediaries); Indonesia's National Family Planning Coordinating Board, Bank Rakyat Indonesia (BRI) and the pawn-brokerage Perum Pegadaian; Agricultural Bank of Turkey and Thailand's Bank for Agriculture and Agricultural Co-operatives (BAAC).
} 
balance, account fees, documentation requirements to open an account, characteristics of accounts (limits on no. of withdrawals); factors influencing branch location; for different categories of loans: paperwork requirements, collateral requirements, factors influencing credit decision and collateral decision, use of credit scoring, rates of interest, fees; cost and speed of different forms of retail payments transaction. Fairly full responses have been received from 23 countries. It is intended to expand the coverage to 90 countries.

The raw results of both of these surveys are currently being processed, and further provider-based sources of information are being explored by researchers at the Bank and the Fund.

A lot of information does reside with providers. They know about the pricing, production costs and frequency of use of different services and products (including, for example, the possible cost efficiencies of new modes of service delivery to low income persons). They should also have this information by geographic location of the point of service. Where they may not have much information is on the characteristics of their customers. Indeed, many banks still do not integrate information on different accounts held by the same customer and as such do not know how many different customers they have.

\section{Credit registries}

Nevertheless, increasing computerization of banks' administrative records and the growth of public or private credit registries allows the creation of usable databases. Importantly, these databases can include time series information about rather small firms otherwise costly to survey. For example, A large Indian bank provided a detailed data set to researchers Banerjee and Duflo (2003), containing information about its lending relationships with about two hundred small and medium-sized firms in the period 19962002. More than half of the firms were in the "small" category, having less than $\$ 150,000$ worth of machinery and equipment assets. This data covered firm characteristics such as turnover, asset size, profits as well as the credit line, utilization and interest rate.

Credit registry-based data allow multiple banking relationships of a single borrowing firm to be tracked. ${ }^{28}$ For example, the State Bank of Pakistan was in a position to produce a complete database of the 113,000 business loan accounts relationships 19962002, including information about the fluctuating size of different classes of loan, default rates, and identification of the firm and its directors, potentially allowing a merger of the information with other firm databases. ${ }^{29}$

\section{Complementarities between provider and user surveys}

Among the many tasks that can be performed through provider surveys are some that overlap with user surveys at least in regard to the scale of access (even if the providers

\footnotetext{
${ }^{28}$ Credit registry data is the basis also of the balance sheet and income statement information for 7 of the 11 European countries in the BACH database. This data is built on a consistent basis for these countries and for the US and Japan, but it presented in aggregate form for 23 sectors and three size classes.

${ }^{29}$ See Mian and Khwaja (2004) for a use of this dataset to study apparent patterns of political corruption in lending.
} 
have only limited information about their customers). However, the provider's view of its customers' and non-customers' access to financial services may be seriously deficient. An interesting comparison between provider surveys and user surveys is obtained by the Genesis/Finmark study of Swaziland mentioned earlier. In a first, provider survey, estimated access percentages for transactions accounts, savings accounts, credit and insurance were obtained by surveying experts and providers. However, as became clear in the subsequent design and implementation of a 600-household survey on usage of financial services, neither the range of providers nor the close substitute services had been adequately covered in the provider survey. Access as measured by household respondents was over twice that measured in the provider survey. ${ }^{30}$ The main reason was that the providers and experts surveyed at the provider stage were not sensitized to the importance of nontraditional forms of the services being examined. The banks gave data on full-service transactions accounts, but did not mention ATM-enabled savings accounts; the importance of store credit, of savings at informal savings clubs (stokvels) and of insurance with burial societies were all neglected at that stage. Of course these aspects could have been surveyed if they had been explicitly considered, but the process of considering matters from the household's side, as in designing and piloting a household survey, is far more likely to elicit a fuller understanding of the substitute products and services for certain traditional formal financial sector products.

\section{Expert surveys.}

Experts can be surveyed in order to obtain information about conditions that are general across the economy as whole or some region of it. Highly relevant examples would be the surveys of Transparency International and the World Bank's Doing Business team. The respondents to the community-level questionnaires in the LSMS and similar household conditions surveys are also expert respondents in this sense.

The sort of information that can be sought in this way includes such matters as how much it costs and how many days it takes to create a new limited liability company, or to recover on a collateral in the case of a loan default. Specific questions of law would also fall into the same category. Here there is no need to collect information about how many participants and the total value of assets, instead the facts being elicited relate to matters on which any well-informed expert should have a clear opinion based on their knowledge of the field and on which experts should generally agree. Sometimes the matters are rather subjective, but even here the hope is that experts will not differ by much and therefore that there will be no need to poll a large number of experts. As such, expert surveys are relatively rather inexpensive. ${ }^{31}$ Expert surveys can be invaluable for

\footnotetext{
${ }^{30}$ Thus the provider survey estimated $7.4 \%$ of households as having transactions accounts, whereas when ATM transaction-enabled savings accounts were included, 19 per cent of households reported their use. 46 per cent of households reported having savings accounts, compared with 28 per cent as estimated by the provide survey; the main reason was the wide use of informal savings clubs called Stokvels, in addition to the deposits at credit cooperatives which had been recorded in the provider surveys.

${ }^{31}$ Indeed, the number of experts polled in some well-established expert surveys seems perilously smallleaving the surveys potentially open to manipulation as well as to small sample errors. According to the Doing Business website, even for a country the size of China, only 10 independent experts provided all of the responses; for five of the eight different themes explored, no more than one independent expert was
} 
completing the picture of the environment in which microfinance is operating. The experts need not be providers, indeed conflict of interest considerations suggests that it is probably better when they are not. (The Doing Business survey has used central bankers among those responding to questions about credit availability, and registrars for questions relating to registries.)

\section{The way forward: much known, much missing State of knowledge}

We have proposed a basic framework within which the analysis of the interesting questions: (i) how does access affect poverty and productivity and (ii) what hinders access, can be considered. These questions need information from user surveys, both household and business, and from surveys of providers and their regulators. Expert surveys will be a necessary complement. ${ }^{32}$

It will be evident from the discussion so far that quite a lot of relevant information has been collected, that its reliability, timeliness, comprehensiveness and comparability all remain somewhat deficient. On the other hand, less efforts have so far been made to bring together what is available - the Doing Business study and The Mix's effort and Christen et al. (2004) being notable exceptions. Doing so will help raise awareness of the access issue in general, as well as allowing countries to begin to benchmark their financial systems even on simple criteria such as percentage of households with deposits or loans from the financial sector.

The program of business user surveys is moving ahead well. While the questionnaire would benefit from an overhaul, the extent of country coverage and the usefulness of the information collected in the PICS is indisputable.

The position with regard to household surveys is somewhat less satisfactory, despite recent advances for a few countries. Even if the right questions are being asked, they are not being asked in a sufficiently large number of countries. Perhaps now is the time to launch a new wave of specialized household surveys of financial service usage, building on what has been learnt from the specialized cases mentioned in Section 2 above, and seeking co-financing from financial service providers who could make use of the results for market development.

\section{National basic access indicators}

In addition to providing the essential raw material for research, both of the fundamental, academic type, the policy-oriented and that useful for the market, there is a need for a set of basic high-profile national summary indicators - the GDP, M2 and CPI of the world of access. These indicators will not by themselves prove anything, but in the early years of

used. (By the qualification 'independent' I mean disregarding multiple respondents from the same law firm or accountancy practice). Nor is the Chinese case unrepresentative in this regard.

32 Recent co-ordinated efforts to document the flow of international remittances provide a good example of the combined use of multiple sources (cf. the papers prepared for a recent APEC conference at http://www1.worldbank.org/finance/html/amlcft/ARS\%20Research\%20Papers.htm). 
what is a new global focus on access to finance, they will serve as an awareness-raising exercise and a point of departure for reforms. Necessarily crude in themselves, and likely to be especially deficient in drilling down to the distributional aspects as between different income groups or social classes, subnational regions or geographical ethnicities, the basic indicators will nevertheless tend to indicate a country's overall success level in achieving access to financial services.

This is not the place to propose precise definitions, but merely to suggest the main elements of a set of national basic indicators. As suggested above, these could be organized around the five functions of finance and the cost barriers to access outlined in Section 2. The other two barriers seem either too qualitative to lend themselves to an obvious national basic indicator, or overlap with one or more of the function indicators. Table 2 suggests a possible list of some twenty such indicators covering about ten distinct dimensions which would be both feasible and provide reasonable coverage of the main areas already discussed. These indicators could be supplemented as well as subclassified but a round number of twenty seems a good starting point.

Despite all of the data that has been collected as discussed in previous sections, it seems fair to say that anyone attempting now to construct a table providing data on each of the 20 indicators for many countries would find it hard to fill in more than a handful of the cells. This emphasizes the gaps in our knowledge as well as the potential for relatively quick progress.

To be sure, even the straightforward indicators listed in Table 1 are crude and potentially misleading. This is readily exemplified by the measures of credit penetration. After all, many households can function fully without any indebtedness and express no demand for it, some would be uncreditworthy even to the most sophisticated financial system. So in measuring the proportion of households with credit, even distinguishing between residential mortgages and other credit, one hundred per cent is hardly a goal. On the other hand, an element of credit is bundled into one of the most common retail payment systems in advanced countries, namely the credit card - even for those who have no demand for credit per se. Measuring the percentage who have sought credit and been refused, plus those who have not sought credit because they did not want to have it - the discouraged borrowers - (all of these to include the low-income owners of micro enterprises) looks like the best compromise indicator, but is far from perfect.

The question arises as to whether these basic indicators should be combined with others and processed into more synthetic or multi-purpose indicators. ${ }^{33}$ On the whole, the

\footnotetext{
${ }^{33}$ First, the basic indicators could be normalized by some national scale variable. For example, taking the indicator of usage of deposits, the simple indicator proposed, i.e. the proportion of households who have deposit accounts at a bank or depository institution, (to include semi -formal intermediaries such as credit unions and specialized MFIs), this proportion would vary widely from country to country, likely ranging from somewhere around 10 per cent in a few low-income countries to well over 90 per cent in some of the advanced economies. It has been suggested by some observers that affordability and current technology indicate that the threshold of bankability may correspond roughly to the $\$ 2$-a-day international poverty line (Genesis, forthcoming). This likely understates the potential for future technology improvements, but points to a useful possible normalization. Expressing the unbanked as a percentage of the poverty
} 
correct answer at this stage seems to be no: for the present, clarity and simplicity of the suggested measures outweighs any advantages that sophistication could bring.

Research use of existing surveys

Also problematic, though it has not been reviewed here, is the degree to which existing data has been used for research purposes, though the position here seems to be changing. Funding for a ramped-up program of research could be considered. This could begin with a first wave assembling experienced applied micro researchers to carry out methodologically innovative work on the income and productivity contribution of access to finance, and on the barriers to access, based on the existing micro data sets. Then in a second phase, post-doctoral research fellowships could be offered to developing country researchers for applying these methodologies to what would by then be a growing set of available micro survey results.

\section{Concluding remark}

The list of proposed national basic financial access indicators and the potential for much more research based on micro surveys highlights the desirability of pushing forward on each of the four main modes of data collection. Given comparative advantage, this suggests efforts on the part of several international agencies as well as partnerships with national regulators and private sector financial service providers.

headcount at the \$2-per-day level in an international comparison would tend to indicate the degree to which some countries' financial access was greater or less than the overall level of development. However, the underlying reasoning here is not universally accepted and any such normalization risks being seen as a black-box obscuring rather than assisting understanding.

Second, different dimensions of usage or cost barriers could be aggregated in some weighted average. Here again, the absence of general agreement on the appropriate weights argues against attempting, at the present s tate of knowledge, to set an international standard aggregate. 


\section{References}

Atkinson, A.B. and F. Bourguignon. 2000. "Income Distribution and Economics." in their Handbook of Income Distribution (Amsterdam: Elsevier), Vol. 1, pp. 1-58.

Banerjee, Abhijit and Esther Duflo. 2003. "Do firms want to borrow more: Testing Credit Constraints using a targeted lending Program." Harvard University Bureau for Research in Economic Analysis of Development BREAD working paper number 2003-5. http://econwww.mit.edu/faculty/download pdf.php?id=434

Basu, Priya and others. 2004. Scaling-up Access to Finance for India's Rural Poor. World Bank. Draft Report.

Batra, Geeta, Daniel Kaufmann and Andrew H. W. Stone. 2003. Investment Climate around the World: Voices of the Firms from the World Business Environment Survey. Washington, DC: The World Bank.

Beck, Thorsten, Asli Demirguç-Kunt and Vojislav Maksimovic. 2003a. "Financial and Legal Constraints to Firm Growth: Does Firm Size Matter?" World Bank Policy

Research Working Paper. Journal of Finance, forthcoming. http://econ.worldbank.org/files/12029_wps2784.pdf

Beck, Thorsten, Asli Demirguç-Kunt and Vojislav Maksimovic. 2003b. "Bank Competition, Financing Obstacles and Access to Credit." World Bank Policy Research WP 2996. Journal of Money Credit and Banking, forthcoming. http://econ.worldbank.org/files/24875 wps2996.pdf

Beck, Thorsten, Asli Demirguç-Kunt and Maria Soledad Martinez Peria. 2004. World Bank Survey on Access to Financial Services, Questionnaires. mimeo.

Bigsten, Arne, Paul Collier, Stefan Dercon, Marcel Fafchamps, Bernard Gauthier, Jan Willem Gunning, Mans Soderbom, Abena Oduro, Remco Oostendorp, Cathy Patillo, Francis Teal, Albert Zeufack. 2003. "Credit Constraints in Manufacturing Enterprises in Africa." Journal of African Economies 12(1): 12-33.

Board of Governors of the Federal Reserve System. 2002. Report to the Congress on the Availability of Credit to Small Businesses. Board of Governors of the Federal Reserve System. Washington, D.C. http://www.federalreserve.gov/boarddocs/rptcongress/sbfreport2002.pdf

Caskey, John P., Clemente Ruíz Durán and Tova Maria Solo. 2004. “The Unbanked in Mexico and the United States." World Bank, mimeo.

Chaves, Rodrigo, Susana Sanchez, Saul Schor, Emil Tesliuc. 2001. Financial Markets, Credit Constraints and Investment in Rural Romania. World Bank Technical Paper No. 499. 
Christen, Robert Peck, Richard Rosenberg and Veena Jayadeva. 2004. "Financial Institutions with a Double Bottom Line: Implications for the Future of Microfinance." Washington DC: CGAP, Occasional Paper 8. http://www.cgap.org/docs/OccasionalPaper 8.pdf

Clarke, George, Robert Cull and Maria Soledad Martinez Peria. 2001. "Does Foreign Bank Penetration Reduce Access to Credit in Developing Countries? Evidence from Asking Borrowers." World Bank Policy Research Working Paper 2716. http://econ.worldbank.org/files/2602 wps2716.pdf

Daley-Harris, Sam. 2003. "State of the Microcredit Summit Campaign Report 2003." mimeo. http://www.microcreditsummit.org/pubs/reports/socr/2003/SOCR03-E[txt].pdf

Genesis Analytics. 2004. A Survey of the SADC Region: South African Financial Institutions, Regional Policies and Issues of Access. mimeo. http://www.finmarktrust.org.za/documents/2004/JUNE/SADCSurvey.pdf

Honohan, Patrick. 2004. Financial Sector Policy and the Poor. Working Paper No. 43. Washington, D.C.: The World Bank. http://econ.worldbank.org/programs/finance/topic/accessfin/library/

Kempson, Elaine, Claire Whyley, John Caskey and Sharon Collard. 2000. "In or out? Financial Exclusion: A Literature and Research Review." London: Financial Services Authority. http://www.fsa.gov.uk/pubs/consumer-research/crpr03.pdf

Kumar, Anjali, Thorsten Beck, Cristine Campos and Soumya Chattopadhyay. 2004. Assessing Financial Access in Brazil. Washington, DC: World Bank.

Levine, Ross. 1997. "Financial Development and Economic Growth: Views and Agenda." Jounal of Economic Literature 35: 688-726.

Littlefield, Elizabeth, Jonathan Morduch and Syed Hashemi. 2003. "Is Microfinance an Effective Strategy to Reach the Millennium Development Goals?" CGAP Focus Note 24. http://www.cgap.org/docs/FocusNote 24.html

Mian, Atif and Asim Ijaz Khwaja. 2004. "Corruption and Politicians: Rent-seeking in an Emerging Financial Market.” University of Chicago. mimeo. http://www.gsb.uchicago.edu/fac/atif.mian/research/PoliticalLending.pdf

Orozco, Manuel. 2004. "The Remittance Marketplace: Prices, Policy and Financial Institutions." Washington DC: Pew Hispanic Center, mimeo. http://www.pewhispanic.org/site/docs/pdf/Remittances\%20june\%2004\%20final.pdf

Ratha, Dilip. 2003. "Worker's Remittances: An Important and Stable Source of External Development Finance." in World Bank, Global Development Finance: Striving for Stability in Development Finance, Volume I: Analysis and Statistical Appendix. Washington, D.C.: World Bank. pp. 157-75. 
Rutherford, Stuart. 2000. The Poor and their Money. Delhi; Oxford University Press.

Rutherford, Stuart. 2002. "Money Talks: Conversations with Poor People about Managing their Money." University of Manchester Institute for Development Policy and Management, Working Paper No. 45. 
Table 1: Countries covered by PICS surveys. October 2004

\begin{tabular}{llll}
\hline Albania & Czech & Latvia & Slovakia \\
Algeria & Ecuador & Lithuania & Slovenia \\
Armenia & Estonia & Moldova & Tajikistan \\
Azerbaijan & Ethiopia & Montenegro & Tanzania \\
Bangladesh & Macedonia FYR & Nicaragua & Turkey \\
Belarus & Georgia & Nigeria & Uganda \\
Bosnia \& Herzegovina & Guatemala & Pakistan & Ukraine \\
Bolivia & Honduras & Peru & Uzbekistan \\
Brazil & Hungary & Philippines & Yugoslavia \\
Bulgaria & India & Poland & Zambia \\
Cambodia & Kazakhstan & Romania & \\
China & Kenya & Russia & \\
Croatia & Kyrgyzstan & Serbia & \\
\hline
\end{tabular}


Table 2: Possible Basic National Indicators

$\gg>N B$ : Please consider this as no more than an indicative and tentative sketch $<<<$

\begin{tabular}{|c|c|c|c|}
\hline Category & Dimension & Indicator & Sources \\
\hline \multicolumn{4}{|l|}{ Functions } \\
\hline Payments & $\begin{array}{l}\text { Transactions } \\
\text { penetration }\end{array}$ & $\begin{array}{l}\% \text { of households with transactions accounts, payments cards; total number of } \\
\text { transactions accounts, payments cards in system. }\end{array}$ & $\begin{array}{l}\text { Household surveys; } \\
\text { Provider* surveys }\end{array}$ \\
\hline $\begin{array}{l}\text { Savings } \\
\text { mobilization }\end{array}$ & $\begin{array}{l}\text { Deposit } \\
\text { usage }\end{array}$ & $\%$ of households with savings accounts; total number of deposit accounts. & $\begin{array}{l}\text { Household surveys; } \\
\text { Provider surveys }\end{array}$ \\
\hline \multirow[t]{3}{*}{$\begin{array}{l}\text { Allocation of } \\
\text { funds }\end{array}$} & \multirow[t]{3}{*}{ penetration } & $\begin{array}{l}\% \text { of households with residential mortgage; other borrowings in last year } \\
\text { (flow, stock); }\end{array}$ & \multirow[t]{3}{*}{$\begin{array}{l}\text { Household surveys; } \\
\text { Enterprise surveys }\end{array}$} \\
\hline & & $\begin{array}{l}\% \text { of enterprises (including unincorporated enterprises) with borrowings } \\
\text { from formal financial intermediaries; }\end{array}$ & \\
\hline & & $\begin{array}{l}\% \text { of enterprises reporting credit refusal in last year or discouraged } \\
\text { borrower. }\end{array}$ & \\
\hline Monitoring users & $\begin{array}{l}\text { Information } \\
\text { technology }\end{array}$ & Coverage of credit registries. & Expert surveys \\
\hline Transforming risk & $\begin{array}{l}\text { Insurance } \\
\text { penetration }\end{array}$ & $\%$ of households with life; motor; household insurance. & \\
\hline \multicolumn{4}{|l|}{ Barriers } \\
\hline \multirow[t]{3}{*}{ Cost } & \multirow[t]{3}{*}{$\begin{array}{l}\text { Banking } \\
\text { charges }\end{array}$} & $\begin{array}{l}\text { All-in cash cost of maintaining standard transactions account (lowest } \\
\text { quartile of intermediaries); }\end{array}$ & \multirow[t]{3}{*}{$\begin{array}{l}\text { Provider surveys; } \\
\text { Expert surveys. }\end{array}$} \\
\hline & & $\begin{array}{l}\text { Cost of standard internal retail payment; Cost of standard international } \\
\text { remittance from relevant source country; }\end{array}$ & \\
\hline & & $\begin{array}{l}\% \text { of households more than one hour traveling distance from a bank } \\
\text { branch by public transport. }\end{array}$ & \\
\hline
\end{tabular}

*Such surveys would typically be carried out by central banks or other national statistical authorities. 


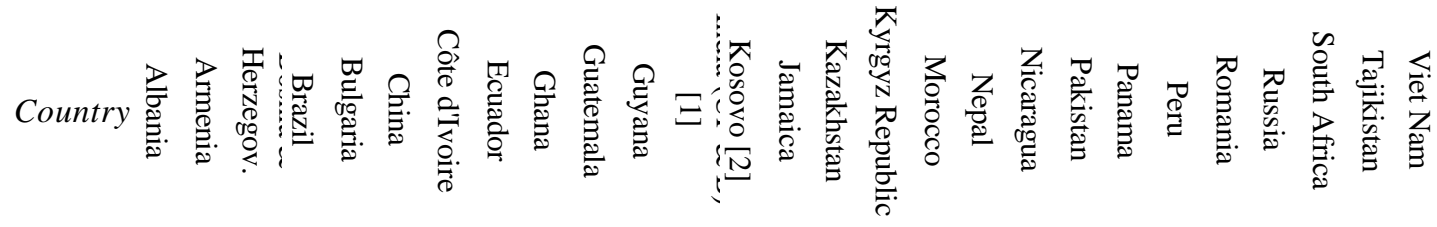

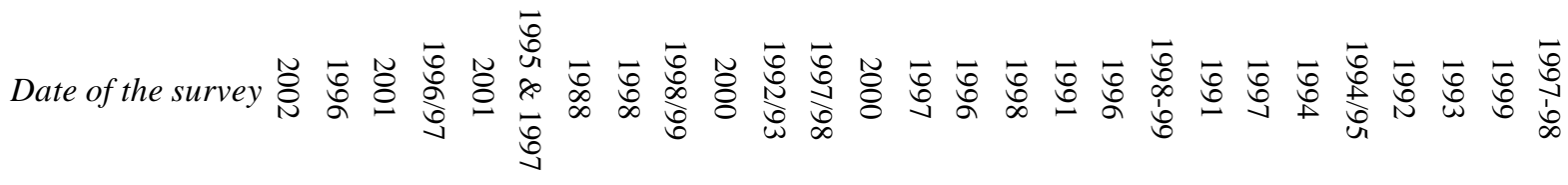

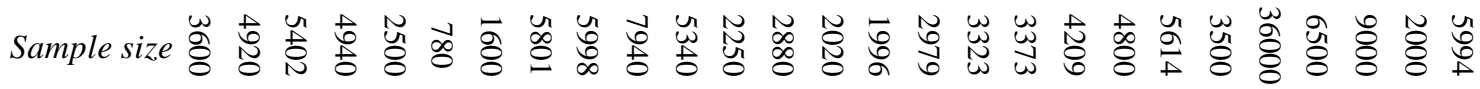

\section{Loan or credit-related questions}

Jid you borrow in the past 12 months?

Jources of the credit?

Main reason for borrowing?

How much did you borrow?

What kind of documents needed to get the loan?

Jow much of the loan still outstanding?

How much loan commission?

The time taken to obtain loan?

?ayment schedule or maturity?

Annual interest rate and for how long?

Jollateral or guarantee provided?

Joans from private individuals and how much?

How often borrow from friends, others or banks?

Jow much do you think your family could borrow?

Were you refused a loan during the last 12 months?

Why was the loan refused?

Why did you not attempt to borrow?

Jistance to lenders

Jurchase on credit (where, for what products, leposits, guarantees, interest)

Mortgage related questions

\section{Savings and deposits-related questions}

Jid you save in the past 12 months?

Total amount of savings held by your household?

Where did you save it?

nterest from saving accounts

Jistance from your home to the place of deposit?

Money taken from savings

What is the main reason for not saving money?

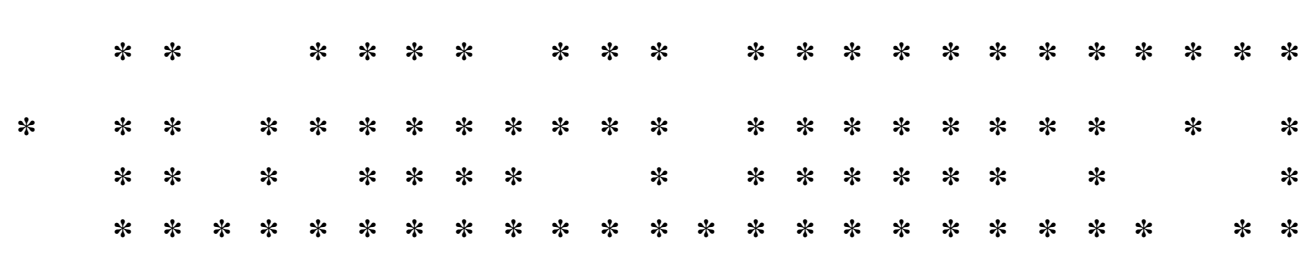

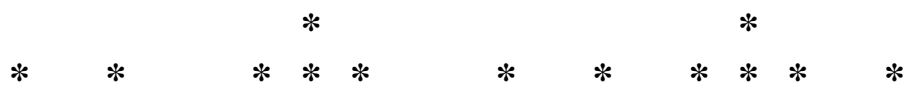

$* \quad * \quad * * *$

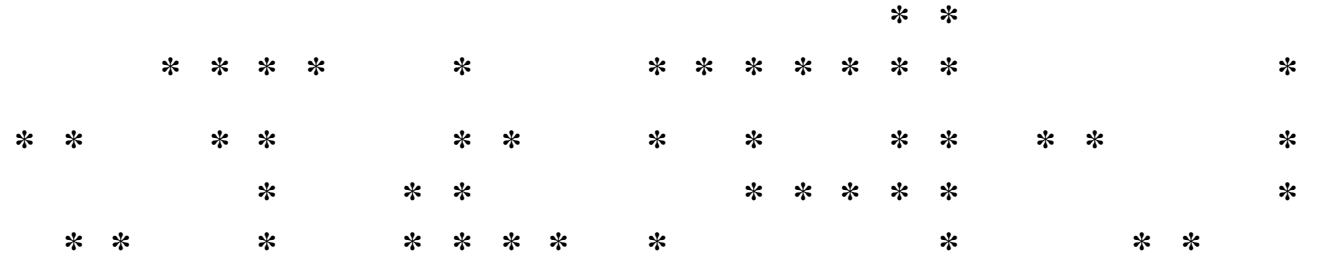

* $\quad * \quad *$

$*$

$*$

$*$

* *

* $\quad *$

* $\quad *$
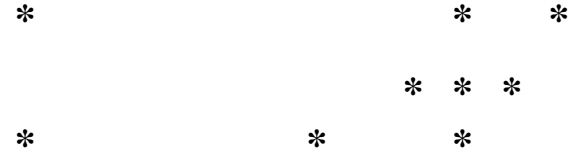

$*$

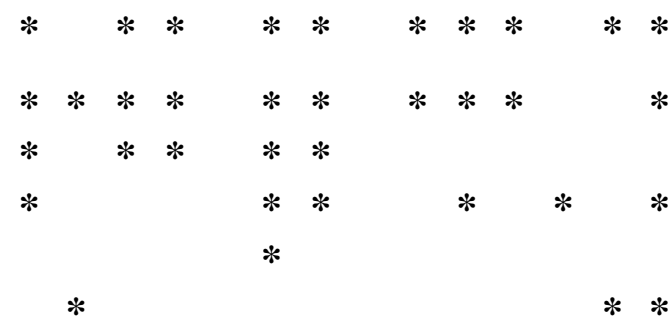


Appendix Table: Main finance questions in recent LSMS surveys (Continued)

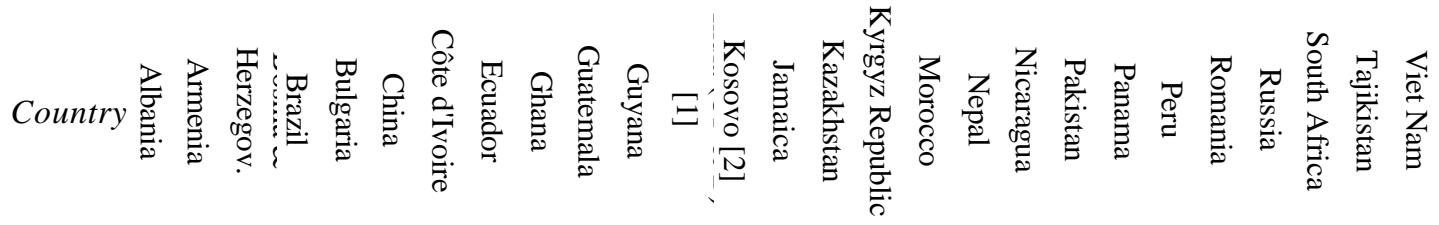

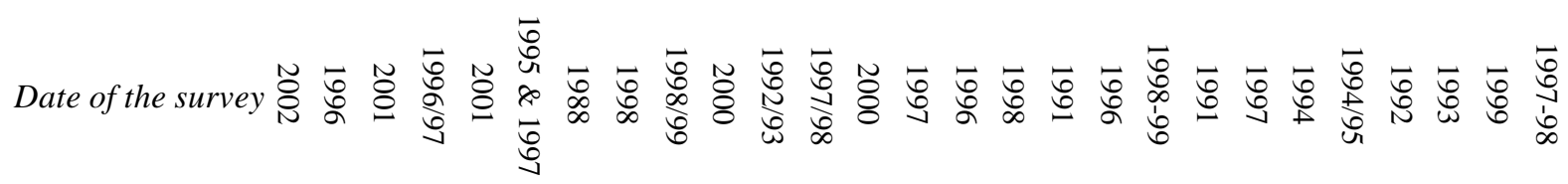

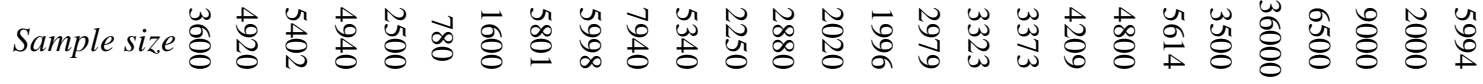

\section{Household as Lender}

Did your family lend money to others; how many?

How much did you lend to others?

Relationship to borrower?

Distance between you and the borrower?

Loan payment schedule; additional fees?

What the money was used for?

Interest received in the past 12 months

How much money owed to you with interest?

Collateral questions on the loan
$* *$

* *

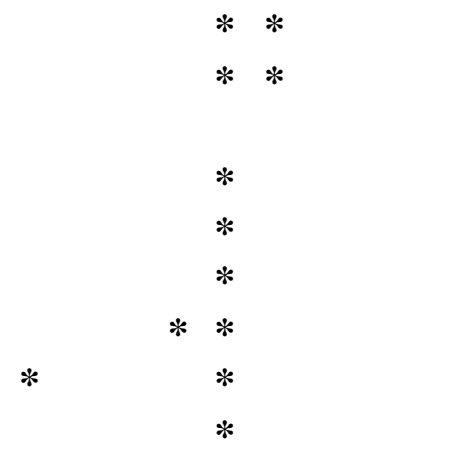

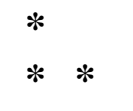

$* * * * *$

* * * * *

* * *

* *

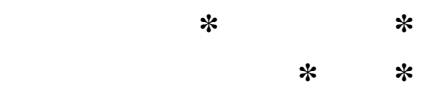

$\begin{array}{lllll} & * & * & * & \\ * & * & * & * & *\end{array}$

Notes: [1] Uttar pradesh and Bihar

[2] Yugoslavia 